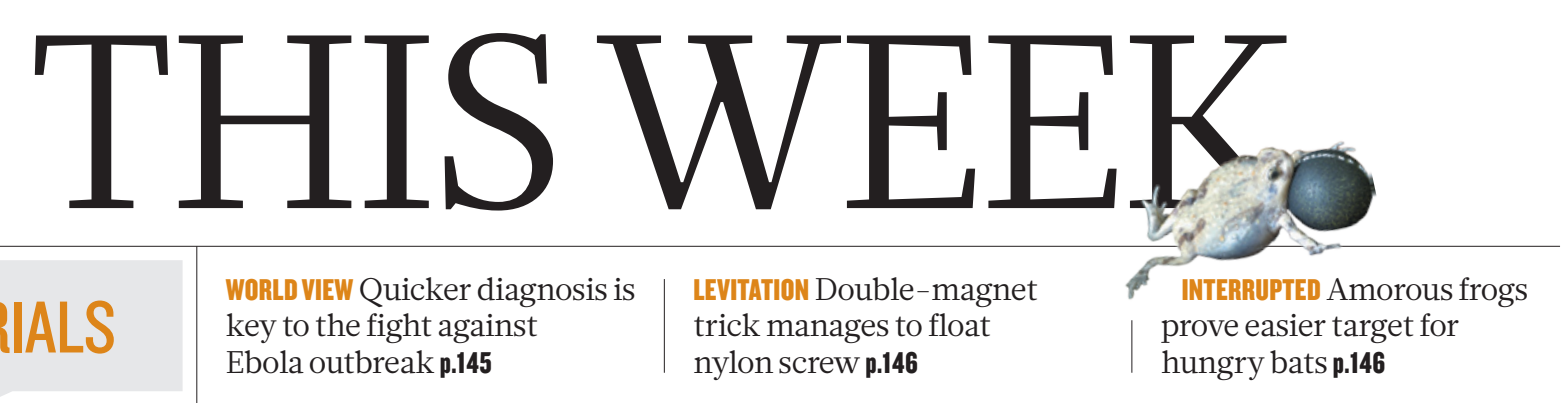

EDITORIALS Ebola outbreak $\mathbf{p} \mathbf{1 4 5}$ trick manages to float

nylon screw $\mathbf{p} .146$

\title{
Genetic rights and wrongs
}

\author{
Australia's decision to uphold a patent on biological material is in danger of hampering the \\ development of diagnostic tests.
}

$\mathrm{I}$ $\mathrm{t}$ is perhaps unexpected that the United States - the oft-lampooned home of patents on peanut-butter-and-jelly sandwiches and ways to swing a swing — is emerging as one of the most hostile towards patents on naturally occurring genes.

Last week, Australia had the opportunity to join the United States in taking a dim view on such licensing of nature. But a federal court there instead upheld a patent claim on the cancer-associated gene BRCA1. In doing so, the country remains with Canada, Japan and several countries in the European Union, all of which, unlike the United States, recognize such patents.

The patent on BRCA1 has become a touchstone in the debate over 'gene patents', a broad term that can cover a wide swath of patent claims on DNA sequences. Certain mutations in BRCA1 increase the risk of, in particular, breast and ovarian cancers. And Myriad Genetics, a genetic-testing company in Salt Lake City, Utah, has aggressively defended its patents, which cover the abnormal BRCA1 sequence and tests to identify it.

In the United States, debate on gene patenting has been tied to clear public-health concerns. Myriad's monopoly bred worry that women would have only a single option for BRCA1 testing, with no possibility of receiving a second, confirmatory test elsewhere. So when advocates challenged US patents on BRCA1 and the closely related gene, BRCA2, the case provoked a passionate response from the public. The patents were defeated in a landmark decision last year that changed decades of legal practice in the field (see Nature 498, 281-282; 2013).

Australia is in a different situation. The BRCA patents have not been enforced there, either by Myriad or by the company that has licensed them in Australia: Genetic Technologies of Melbourne. Despite the fervent involvement in the case of patient advocates, including cancer survivors, the spectre of gene patents in Australia remains more theoretical.

Still, the case, and the attention it has received, shines new light on how such patents will affect the future of medical diagnostics, particularly as genetic tests expand to cover large numbers of genes, and even the full genome.

In the run-up to the US decision on Myriad, an academic subfield was born from a handful of patent lawyers and scholars who wanted to know just how many gene patents might be affected - no easy task in a system that awards around 300,000 patents a year. Answers varied, but the general conclusion was: not as many as you might think. One study found that most patents that mention DNA sequences do not claim the sequences as an invention (O. A. Jefferson et al. Nature Biotechnol. 31, 1086-1093; 2013). Nevertheless, even a few hundred patents on genes can be enough to scare off potential investors and entrepreneurs looking to pioneer methods of genetic testing, because they might infringe on protected genetic property.

In the United States, gene patents were defeated because they ran afoul of a prohibition on patents claiming a "product of nature". An influential brief to the US Supreme Court written by biologist Eric Lander, head of the Broad Institute in Cambridge, Massachusetts, wounded the held idea that isolating DNA changed it from a product of nature to a human product, thereby making it patentable. He pointed out that 'isolated' bits of DNA can be found floating free in the blood, and that the isolated $B R C A 1$ and BRCA2 genes had in fact been found doing just that.

In Australia, no such limitation on patenting natural products exists. Instead, the debate there has centred on whether the patent claims a "method of manufacture". Last week, five Australian justices unanimously ruled that it does, because to isolate "Debate on gene DNA from its natural setting requires effort. patentinghas This, they say, describes "an artificially crebeen tied to clear ated state of affairs for economic benefit", and public-health is therefore fair game for a patent.

concerns." The plaintiffs in the case are considering an appeal to the High Court of Australia, and some patient advocates are crying for changes to the law to do away with gene patents.

For now, the Australian decision is certain to please patent lawyers and some biotechnology executives. This seems to have been the justices' intent: the bulk of their rulings have focused on preserving incentives for innovation and business. There has been little, if any, attention from the court to what this means for science, or for patient access to information about their genes.

Business concerns are important: the biotechnology industry depends on patents for its livelihood, and many patients' lives depend on the industry. But the business model pursued by Myriad is a fading one, and it is time to look to the future. That future has little place for patents that could hold up the development of bigger and better medical tests.

\section{Ebola: time to act}

\section{Governments and research organizations must mobilize to end the West African outbreak.}

fter disproportionate media attention on Ebola's negligible risk
to people in Western and Asian countries, the focus seems at
last to be shifting towards how to stop the outbreak in West
Africa. The grim reality is that medical organizations are struggling:
the flood of new cases far outpaces available beds and treatment
centres. Many of those who are ill are not receiving the basic health
care that could keep them alive.
The tragedy is that we know how to stop Ebola. Well-informed
communities can reduce the main routes of spread by avoiding 